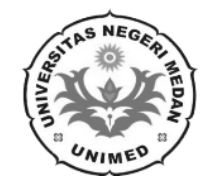

\title{
Pengaruh Kinerja Lingkungan Terhadap Kinerja Keuangan Dengan Corporate Responsibility Sebagai Variabel Intervening Pada Perusahaan Manufaktur Yang Terdaftar Terdaftar Di Bursa Efek Indonesia Tahun 2015 - 2017
}

\author{
Marini Yuniarti ${ }^{1}$, Tapi Rumondang Sari Siregar ${ }^{2}$ \\ Universitas Negeri Medan \\ Mariniyuniarti44@gmail.com ${ }^{1}$, tapirumondangsiregar@gmail.com ${ }^{2}$
}

\begin{abstract}
This research is about the problem of environmental performance on financial performance with corporate social responsibility as an intervening. This study aims to determine the Influence of Environmental Performance on Financial Performance with Corporate Social Responsibility as an intervening variable in manufacturing companies listed on the Indonesia Stock Exchange and participate in the Corporate Performance Assessment Program (PROPER) of the Ministry of Environment of the Republic of Indonesia. The research period used is 2015-2017. The population in this study are Manufacturing Companies listed on the Indonesia Stock Exchange and participate in the Corporate Performance Assessment Program (PROPER) of the Ministry of Environment of the Republic of Indonesia in the 2015-2017 observation period. The research sample was taken using a purposive sampling method . 24 Manufacturing Companies obtained as samples. The results of the first hypothesis analysis indicate that the results of the $t$ test for environmental performance variables obtained a significance value of 0.096 , which means greater than 0.05 . While in the second hypothesis, the test results are seen from the significance value of the environmental performance variable of 0.001 which means less than 0.05 . Furthermore, the third hypothesis is calculated by multiplying the indirect coefficient, namely $((0,051) \times 13,236)=0,675036$ so that the total effect becomes $(0,498+(0,051) \times 13,236))=1,173036$. This means that the level of indirect influence of Environmental Performance on financial performance is 1,173036 greater than the direct relationship coefficient of 0,498. Based on the results of data analysis it can be concluded that: (1) Environmental Performance does not affect Financial Performance . (2) Environmental Performance has a positive and significant effect on Corporate Social Responsibility . (3) Partially Environmental Performance has a positive and significant effect on Financial Performance with Corporate Social Responsibility as an intervening variable.
\end{abstract}

Keywords: environment performance, financial performance, corporate social responsibility 
Pengaruh Kinerja Lingkungan Terhadap Kinerja Keuangan Dengan Corporate Responsibility Sebagai Variabel Intervening Pada Perusahaan Manufaktur Yang Terdaftar Terdaftar Di Bursa Efek Indonesia Tahun 2015 - 2017

\section{Pendahuluan}

Perusahaan dengan dana yang cukup dapat beraktifitas dengan normal terutama dalam pengembangan usaha. Perusahaan manufaktur yang sudah go-public dapat memperoleh pendanaan melalui dua cara yaitu melalui internal dan eksternal perusahaan. Internal perusahaan dapat memperoleh dana melalui kegiatan operasional perusahaan yang memperoleh laba. Sedangkan eksternal perusahaan memperoleh dana salah satunya melalui kegiatan menjual sahamnya di bursa efek. Oleh sebab itu, perusahaan public memiliki stakeholders yang perlu mengetahui bagaimana kinerja perusahaan. Mereka melihat pada laporan keuangan perusahaan yang diumumkan secara periodik untuk menyediakan informasi mendasar tentang kinerja keuangan perusahaan, yang selanjutnya akan dianalisis (Atmaja, 2008). Kinerja keuangan perusahaan adalah gambaran baik buruknya kondisi perusahaan dalam periode tertentu yang digunakan sebagai tolak ukur dalam menilai keberhasilan perusahaan dari sisi financial. Kinerja keuangan perusahaan yang baik akan menarik para investor untuk menanamkan modalnya sehingga dapat meningkatkan nilai perusahaan. Kinerja perusahaan juga dapat dilihat melalui kinerja lingkungan yang merupakan bentuk tanggungjawab perusahaan terhadap lingkungan dan masyarakat yang sering disebut tanggungjawab sosial.

Namun seringkali dalam memaksimalkan laba yang akan dicapai, perusahaan tidak memikirkan bagaimana kinerja lingkungan yang baik dan rendahnya kesadaran akan minat terhadap konservasi lingkungan. Permasalahan lingkungan menjadi perhatian baik oleh pemerintah, investor, maupun konsumen. Investor memiliki persoalan tentang pengadaan bahan baku, dan proses produksi yang harus terhindar dari munculnya masalah lingkungan seperti: kerusakan tanah, rusaknya ekosistem, dan polusi udara yang mengganggu kehidupan masyarakat sekitar. Selain itu di Indonesia sendiri belakangan ini banyak terdapat berbagai konflik industri seperti kerusakan alam akibat eksploitasi alam tanpa di imbangi dengan perbaikan lingkungan ataupun memperhatikan keseimbangan alam sekitar seperti adanya limbah ataupun polusi pabrik yang sangat merugikan lingkungan sekitarnya. Pencemaran lingkungan terjadi disebabkan oleh perkembangan kegiatan industri yang mengubah fungsi lahan menjadi kawasan industri. Dampak sosial yang terjadi terhadap kehidupan masyarakat sangat besar yang pada akhirnya mengganggu kehidupan atau aktivitas masyarakat sekitar.

Hal ini diharuskan bagi pemerintah untuk memikirkan kebijakan ekonomi makronya mengenai pengelolaan lingkungan dan konservasi alam. Dalam kebijakan ekonomi pemerintah melalui keputusan Mentri Lingkungan Hidup Nomor : 127/MENLH/2002 membentuk Program Penilaian Peringkat Kinerja Perusahaan dalam Pengelolaan Lingkungan Hidup (PROPER) yang telah dilaksanakan mulai tahun 2002 di bidang pengendalian dampak lingkungan untuk meningkatkan peran perusahaan dalam program pelestarian lingkungan hidup. Kinerja lingkungan perusahaan diukur menggunakan warna mulai dari yang terbaik emas, hijau, biru, merah hingga yang terburuk yaitu hitam. Selanjutnya, perusahaan dengan pengelolahan lingkungan hidup yang baik dapat menyajikan suatu laporan yang menunjukkan kontribusinya terhadap berbagai masalah lingkungan yang terjadi disekitarnya.

\section{Landasan Teori Dan Pengembangan Hipotesis}

\subsection{Landasan Teori}

Kegiatan - kegiatan yang dilakukan oleh perusahaan selalu berdampak pada stakeholders seperti karyawan, pemasok, investor, pemerintah, konsumen, serta masyarakat. Salah satu kewajiban perusahaan yaitu adanyakewajiban memberikan laporan sebagai informasi kedapa para skateholders. Laporan yang wajib diungkapkan perusahaan setidaknya meliputi satu set laporan keuangan. Perusahaan diijinkan untuk mengungkapkan laporan tambahan, yaitu laporan yang berisi lebih dari sekedar laporan keuangan, misalnya laporan tahunan tentang aktivitas CSR perusahaan. Tujuan dari laporan tambahan ini adalah untuk menyediakan informasi tambahan mengenai kegiatan perusahaan sekaligus sebagai sarana memberikan tanda (signal) kepada stakeholder mengenai hal-hal lain, seperti memberikan tanda (signal) tentang kepedulian perusahaan terhadap lingkungan sekitarnya. Signaling theory menekankan bahwa perusahaan pelapor dapat meningkatkan nilai perusahaan melalui pelaporannya.

Selanjutnya, teori legitimasi (Legitimacy theory) berfokus pada interaksi antara perusahaan dengan masyarakat. Teori ini menyatakan bahwa organisasi adalah bagian dari masyarakat sehingga harus memperhatikan norma-norma sosial masyarakat karena kesesuaian dengan norma sosial dapat membuat perusahaan semakin legitimate. Oleh sebab itu, teori legitimasi adalah sebuah kontrak sosial antara 
Pengaruh Kinerja Lingkungan Terhadap Kinerja Keuangan Dengan Corporate Responsibility Sebagai Variabel Intervening Pada Perusahaan Manufaktur Yang Terdaftar Terdaftar Di Bursa Efek Indonesia Tahun 2015 - 2017

perusahaan masyarakat. Jadi apabila masyarakat tidak puas dengan etika dan legitimasi perusahaan tersebut, maka masyarakat dapat menarik kembali kontrak dan selanjutnya mengancam tidak melanjutkan aktivitas operasional perusahaan tersebut (Deegan, 2002). Perusahaan melakukan pengorbanan sosial sebagai wujud perhatian kepada masyarakat, sebagai pernyataan bahwa perusahaan benar-benar peduli akan lingkungan disekitar perusahaan dan pada akhirnya masyarakat memberikan feed back yaitu pandangan positif dan mendukung kegiatan perusahaan tersebut. Oleh karena itu, untuk tetap bisa mewujudkan legitimasi antara perusahaan dan masyarakat, perusahaan harus terus menginformasikan aktivitas lingkungan melalui publikasi pengungkapan lingkungan sosial.

Kinerja keuangan perusahaan dalam aktivitas lingkungan saling berkaitan, dimana kinerja keuangan merupakan gambaran kondisi keuangan perusahaan pada suatu periode tertentu baik menyangkut aspek penghimpunan dana maupun penyaluran dana, yang biasanya diukur dengan indicator kecukupan modal, likuiditas, dan profitabilitas (Jumingan, 2006). Ikatan Akuntan Indonesia (2007) juga mengungkapkan kinerja keuangan adalah kemampuan perusahaan dalam mengelola dan mengendalikan sumber daya yang dimilikinya. Keberhasilan manajemen dalam mengelola perusahaan dapat dilihat dari kinerja keuangannya yang ditunjukkan oleh jumlah penjualan, harta yang dimiliki, tenaga kerja dan analisis rasio, yang disajikan dalam laporan keuangan.

\subsection{Pengembangan Hipotesis}

Perusahaan manufaktur saat ini terus berkembang dengan pesat. Perusahaan tersebut berdiri di tengah - tengah kehidupan masyarakat. Oleh sebab itu, masyarakat yang telah memberikan ruang bagi perusahaan, perusahaan juga harus melakukan sesuatu sebagai timbal baliknya. Semua hal ini digambarkan melalui kinerja perusahaan. Verrecchia (1983) berpendapat pelaku lingkungan yang baik percaya bahwa mengungkapkan performance mereka menggambarkan berita baik bagi pelaku pasar. Oleh karena itu, perusahaan dengan kinerja lingkungan yang baik perlu mengungkapkan informasi kuantitas dan mutu lingkungan yang lebih dibandingkan dengan perusahaan yang memiliki kinerja lingkungan yang buruk. Selain itu, perusahaan yang mampu mengelola kinerja lingkungan, corporate sosial responsibility dan kinerja keuangan dengan baik akan menarik para investor untuk berinvestasi. Dengan meningkatnya citra perusahaan diharapkan dapat meningkatkan kinerja keuangan perusahaan. Pemilihan indicator dari CSR itu sendiri juga mengacu pada adanya hasil penelitian terdahulu. Namun dalam penelitian ini dikaitkan dengan kinerja lingkungan dan kinerja keuangan. Hal ini tidak terlepas dari tujuan perusahaan jangka panjang yaitu peningkatan kinerja keuangan dengan melaksanakan kegiatan CSR kepada lingkungan sekitar.

H1. Kinerja lingkungan berpengaruh terhaddap kinerja keuangan.

H2. Kinerja lingkungan berpengaruh terhadap Corporate Social Responsibility (CSR).

H3. Corporate Social Responsibility (CSR) akan memediaasi kinerja lingkungan terhadap kinerja keuangan.

\section{Metode Penelitian}

\subsection{Populasi Dan Pemilihan Sampel}

Populasi yang digunakan dalam penelitian adalah seluruh perusahaan manufaktur yang telah terdaftar di BEI (Bursa Efek Indonesia) tahun 2015 - 2017 adalah 130 perusahaan. Kriteria pemilihan sampel adalah perusahaan manufaktur yang tidak melaporkan corporate social responsibility dari tahun 2015 - 2017, perusahaan manufaktur yang tidak melaporkan cormporate social responsibility dari tahun 2015 - 2017, perusahaan manufaktur yang tidak mengikuti Program Penilaian Kinerja Perusahaan (PROPER) dari tahun 2015 - 2017 serta perusahaan manufaktur yang tidak menyajikan laporan keuangan dalam bentuk rupiah. Selanjutnya, sampel akan dianalisis menggunakan uji asumsi klasik, dan analisis jalur (path analysis). Setelah dilakukan pemilihan sampel, maka jumlah sampel yang digunakan sebanyak 24 perusahaan dengan jumlah periode pengamatan 3 tahun, sehingga jumlah data yang digunakan dalam penelitian ini sebanyak 72 data penelitian. 
Pengaruh Kinerja Lingkungan Terhadap Kinerja Keuangan Dengan Corporate Responsibility Sebagai Variabel Intervening Pada Perusahaan Manufaktur Yang Terdaftar Terdaftar Di Bursa Efek Indonesia Tahun 2015 - 2017

Tabel 1

Pemilihan Sampel

\begin{tabular}{l|l|c} 
No & \multicolumn{1}{|c|}{ Kriteria Sampel } & $\begin{array}{c}\text { Tahun } \\
\mathbf{2 0 1 5 - 2 0 1 7}\end{array}$ \\
\hline 1 & Perusahaan manufaktur yang terdaftar di Bursa Efek Indonesia dari tahun 2015-2017 & 130 \\
\hline 2 & $\begin{array}{l}\text { Perusahaan manufaktur yang tidak melaporkan corporate social responsibility dari } \\
\text { tahun 2015-2017 }\end{array}$ & $(1)$ \\
\hline 3 & $\begin{array}{l}\text { Perusahaan manufaktur yang tidak mengikuti Program Penilaian Kinerja Perusahaan } \\
\text { (PROPER) dari tahun 2015-2017 }\end{array}$ & $(80)$ \\
\hline 4 & Perusahaan manufaktur yang tidak menyajikan laporan keuangan dalam bentuk rupiah & $(25)$ \\
\hline & Total sampel penelitian & 24
\end{tabular}

\subsection{Definisi Operasional Dan Pengukuran Variabel}

\subsubsection{Kinerja Keuangan}

Kinerja keuangan merupakan penentuan ukuran-ukuran tertentu yang dapat mengukur keberhasilan suatu perusahaan dalam mengelola sumber daya untuk menghasilkan laba. Selain itu, kinerja keuangan juga digunakan oleh manajer dan pihak yang berkepentingan lainnya seperti investor untuk untuk mengambil keputusan dengan cara mengevaluasi kondisi baik buruknya keuangan melalui laporan yang disajikan. Dalam penelitian ini kinerja keuangan diukur menggunakan Tobin's Q. Tobin's Q mewakili sejumlah variabel yang penting dalam pengukuran kinerja, antara lain aktiva tercatat perusahaan, kecenderungan pasar yang memadai seperti pandangan - pandangan analis mengenai prospek perusahaan, dan variabel modal intelektual atau intangible asset. Selain itu, Tobin's Q memiliki keunggulan dari Profit Margin, ROA atau indikator keuangan yang berdasarkan pada historical accounting performance lainnya karena merefleksikan ekspektasi pasar sehingga relatif bebas dari kemungkinan manipulasi oleh manajemen perusahaan. Tobin's Q di gunakan dengan menggunakan rumus sebagai berikut:

\section{Tobin's $\mathrm{Q}=$}

(MVE+DEBT)

\section{Total Aktiva + DEBT}

Dimana, $M V E$ merupakan harga penutupan saham akhir tahun x banyaknya saham biasa yang beredar; $D E B T$ merupakan (utang lancar - aktiva lancar) + persediaan + utang jangka panjang; dan $T A$ merupakan total aktiva.

\subsubsection{Kinerja Lingkungan}

Kinerja lingkungan merupakan upaya perusahaan dalam menciptakan kondisi lingkungan yang baik disekitar perusahaan. Kinerja lingkungan diukur melalui prestasi perusahaan dalam mengikuti PROPER. Program yang merupakan salah satu upaya yang dilakukan Kementrian Lingkungan Hidup (KLH) untuk mendorong penataan perusahaan dalam pengelolaan lingkungan hidup melalui instrument informasi. Sistem peringkat kinerja PROPER mencakup pemeringkat perusahaan dalam 5 warna serta memiliki kriteria peringkat yaitu:

Tabel 2

Peringkat kinerja PROPER

\begin{tabular}{|c|c|l|}
\hline Peringkat & Skor & \multicolumn{1}{|c|}{ Keterangan } \\
\hline $\begin{array}{c}\text { Emas } \\
\text { (sangat sangat baik) }\end{array}$ & 5 & $\begin{array}{l}\text { Telah secara konsisten menunjukan keunggulan lingkungan dalam proses } \\
\text { produksi atau jas, melaksanakan bisnis yang beretika dan bertanggungjawab } \\
\text { terhadap masyarakat. }\end{array}$ \\
\hline $\begin{array}{c}\text { Hijau } \\
\text { (sangat baik) }\end{array}$ & 4 & $\begin{array}{l}\text { Telah melakukan pengelolaan lingkungan lebih dari yang dipersyaratkan } \\
\text { dalam peraturan melalui pelaksanaan sistem pengelolaan lingkungan, } \\
\text { pemanfaatan sumberdaya secara efisien melalui upaya 4R (reduce, reuse, } \\
\text { recycle,dan recovery)dan melakukan tanggungjawab sosial dengan baik. }\end{array}$ \\
\hline $\begin{array}{c}\text { Biru } \\
\text { (baik) }\end{array}$ & 3 & $\begin{array}{l}\text { Telah melakukan upaya pengelolaan lingkungan yang dipersyaratkan } \\
\text { sebagaimana diatur dalam perundang - undangan. }\end{array}$ \\
\hline $\begin{array}{c}\text { Merah } \\
\text { (buruk) }\end{array}$ & 2 & $\begin{array}{l}\text { Pengelolaan lingkungan hidup tidak dilakukan dengan persyaratan } \\
\text { sebagaimana di atur dalam UU }\end{array}$ \\
\hline
\end{tabular}


Pengaruh Kinerja Lingkungan Terhadap Kinerja Keuangan Dengan Corporate Responsibility Sebagai Variabel Intervening Pada Perusahaan Manufaktur Yang Terdaftar Terdaftar Di Bursa Efek Indonesia Tahun 2015 - 2017

\begin{tabular}{|c|c|c|}
\hline $\begin{array}{c}\text { Hitam } \\
\text { (sangat buruk) }\end{array}$ & 1 & $\begin{array}{l}\text { Sengaja melakukan perbuatan atau kelalaian yang mengakibatkan pencemaran } \\
\text { atau kerusakan lingkungan atau pelanggaran terhadap peraturan undang }- \\
\text { undang atau tidak melaksanakan sangsi administrasif. }\end{array}$ \\
\hline
\end{tabular}

\subsubsection{Corporate Social Responsibility}

Corporate Social Responsibility (CSR) merupakan pengungkapan informasi yang berkaitan dengan lingkungan didalam laporan tahunan perusahaan. CSR disclosure diukur denganmenggunakan Index CSR Majemuk. Disini variabel intervening yang berupa CSR (Ekonomi, Lingkungan, Tenaga Kerja, Hak Asasi Manusia, Produk, dan Sosial) diukur pengaruhnya terhadap variabel dependen.

Pendekatan untuk menghitung CSDI pada dasarnya menggunakan dikotomi yaitu setiap item CSR dalam instrumen penelitian diberi nilai 1 jika diungkapkan, dan nilai 0 jika tidak diungkapkan (Sayekti dan Windabio, 2007 dalam Nurika, 2010). Selanjutnya skor dari setiap item dijumlahkan untuk memperoleh keseluruhan skor untuk setiap perusahaan. Indeks pengungkapan masing-masing perusahaan kemudian dihitung dengan membagi jumlah item yang diungkapkan perusahaan dengan jumlah item yang diharapkan diungkapkan perusahaan. Semua ini konsisten dengan penelitian yang sebelumnya yang dilakukan di Indonesia yang dinyatakan dalam Corporate SocialResponsibility Index (CSRI) dengan rumus sebagai berikut :

$$
\mathrm{CSDI}=\frac{\mathrm{V}}{\mathrm{M}}
$$

Dimana: CSDI merupakan Indeks pengungkapan sosial perusahaan; $V$ merupakan jumlah item yang diungkapkan perusahaan; dan $M$ merupakan jumlah item yang semuanya diharapkan diungkapkan oleh perusahaan.

\subsection{Metode Analisis Data}

Analisis data dalam penelitian ini menggunakan analisis deskriptif dimana analisis ini digunakan untuk mendeskripsikan data yang terdiri dari kinerja lingkungan, kinerja keuangan dan cormporate social responsibility. Selanjutnya dilakukan uji asumsi klasik yang terdiri dari uji normalitas, uji multikolineritas, uji autokorelasi, dan uji heteroskedastisitas, Menurut Ghozali (2016:154) uji normalitas digunakan untuk menguji apakah dalam model regresi, variabel independen dan dependen memiliki distribusi normal atau tidak dengan menggunakan uji kolmogrov-Smirnov.s. Ghozali (2016:103) uji multikolinieritas dilakukan untuk mengetahui apakah ada korelasi antar variabel bebas di dalam model regresi. Multikolinieritas dapat dilihat dari nilai Tolerance dan variance inflation faktor (VIF). Jika nilai tolerance $<0,01$ dan nilai VIF > 10 maka model regresi tersebut bebas dari multikolinieritas. Menurut Ghozali (2016:107) uji autokorelasi bertujuan untuk menguji apakah dalam suatu model regresi linier ada kolerasi antar anggota sampel yang diurutkan berdasarkan waktu. Uji heteroskedastisitas bertujuan untuk menguji apakah dalam model regresi terjadi ketidaksamaan residual satu pengamatan ke pengamatan lain (Ghozali 2016:134).

Selanjutnya dalam peneltian ini juga dilakukan uji hipotesis dengan menggunakan analisis jalur. Metode analisis jalur (Path Analysis) digunakan untuk menguji pengaruh variabel intervening. Analisis jalur merupakan perluasan dari analisis regresi linear berganda, atau analisis jalur adalah penggunaan analisis regresi untuk menaksir hubungan kausalitas antar variabel yang telah ditetapkan sebelumnya berdasarkan teori (Ghozali 2016:237). Model persamaan yang digunakan adalah :

$$
\begin{aligned}
& \mathrm{CSR}=\alpha+\mathrm{p} 2 \mathrm{KL}+\mathrm{e} 1 \ldots \ldots \ldots \ldots \ldots \ldots \ldots \ldots(1) \\
& \mathrm{KK}=\alpha+\mathrm{p} 1 \mathrm{KL}+\mathrm{p} 3 \mathrm{CSR}+\mathrm{e} 2 \ldots \ldots \ldots \ldots \ldots \ldots(2)
\end{aligned}
$$

Dimana: CSR (Corporate social Responsibility); $K L$ merupakan kinerja lingkungan; $K K$ merupakan kinerja keuangan; $\alpha$ merupakan konstanta; $p 1$ merupakan koefisien jalur KL dengan KK; p2 merupakan koefisien jalur KL dengan CSR; $p 3$ merupakan koefisien jalur CSR dengan KK; elmerupakan residual atas CSR; dan $e 2$ merupakan residual atas Kinerja Keuangan.

Setelah itu, dilakukan uji simultan (uji F) dimana digunakan untuk mengetahui pengaruh variabel independen terhadap variabel dependen secara bersama - sama dengan melihat nilai $\mathrm{F}$ nya. Tingkat signifikan dalam penelitian ini sebesar $5 \%$. Kriteria pengambilan keputusan terhadap uji $\mathrm{F}$ yaitu jika $\mathrm{F}$ hitung > F tabel, maka H0 ditolak sedangkan jika F hitung < F tabel, maka H0 diterima (Ghozali, 2011). 
Pengaruh Kinerja Lingkungan Terhadap Kinerja Keuangan Dengan Corporate Responsibility Sebagai Variabel Intervening Pada Perusahaan Manufaktur Yang Terdaftar Terdaftar Di Bursa Efek Indonesia Tahun 2015 - 2017

Uji statistik T dilakukan untuk menunjukan seberapa jauh satu variabel idependen secara individual dalam menerangkan variabel independen. Dasar pengambilan keputusan adalah dengan menggunakan angka probabilitas signifikansi yaitu Apabila angka probabilitas signifikansi > 0,05 maka Ho diterima dan Ha ditolak. Sedangkan jika angka probabilitas signifikansi < 0,05 maka Ho ditolak dan Ha diterima (Ghozali 2016:97). Selanjutnya Koefisien determinasi (R2) digunakan untuk mengukur seberapa jauh kemampuan model dalam menerangkan variasi variabel dependen. Nilai koefisien determinansi adalah antara 0 dan 1. Nilai R2 yang kecil berarti kemampuan variabel-variabel independen dalam menjelaskan variasi variabel dependen amat terbatas. Nilai yang mendekati 1 berarti variabel-variabel independen memberikan hampir semua informasi yang dibutuhkan untuk memprediksi variasi variabel dependen (Ghozali, 2011).

\section{Hasil Penelitian Dan Pembahasan}

\subsection{Statistik Deskriptif}

Statistik deskriptif memberikan gambaran atau deskripsi suatu data yang dilihat dari nilai rata-rata (mean), standar deviasi, varian, maksimum, minimum, sum, range, kurtosis, dan skewness (kemencengan distribusi) (Ghozali, 2018).

Tabel 3

\begin{tabular}{l|r|r|r|r|r} 
& $\mathrm{N}$ & Minimum & Maximum & Mean & Std. Deviation \\
& & & & & \\
\hline Kinerjalingkungan & 72 & 2,00 & 4,00 & 2,8472 &, 46451 \\
\hline kinerjakeuangan & 72 &, 27 & 7,65 & 1,1750 & 1,42373 \\
\hline Csr & 72 &, 18 &, 47 &, 2906 &, 06373 \\
\hline Valid N (listwise) & 72 & & & &
\end{tabular}

Dalam penelitian ini yang menjadi variabel dependen adalah kinerja Lingkungan yang diukur dengan Program Peringkat Kinerja Perusahaan (PROPER). Hasil statistik deskriptif untuk variabel ini menunjukkan nilai tertinggi (maximum) sebesar 4,00 dan nilai terendah (minimum) sebesar 2,00 . Nilai rata-rata (mean) dari variabel dependen ini adalah 2,8472. Nilai standar deviasi (standar deviation) untuk kinerja keuanganadalah 0.46451. Selanjutnya variabel independen pertama dalam penelitian ini adalah Kinerja Keuangan yang diukur dengan metode Tobin's $Q$. Hasil statistik deskriptif untuk variabel Kinerja Keuangan menunjukkan nilai maximum sebesar 7,65 dan nilai minimum sebesar 0,27. Nilai mean dari variabel Kinerja Keuangan adalah 1,1750 dan nilai standar deviation adalah1,42373. Variabel independen kedua dalam penelitian ini adalah corporate social responsibility sebagai variabel intervening yang diproksikan dengan indeks GRI G4. Hasil statistik deskriptif untuk variabel corporate social responsibility menunjukkan nilai maximum sebesar 0,47 dan nilai minimum sebesar 0,18 . Nilai mean dari variabel corporate social responsibility adalah 0,2906 dan nilai standar deviation adalah 0.06373 .

\subsection{Pengujian Hipotesis}

Dalam penelitian ini terdapat variabel intervening dimana digunakan untuk menganalisis pola hubungan antara variabel dengan tujuan mengetahui pengaruh langsung maupun tidak langsung seperangkat variabel bebas (eksogen) terhadap variabel terikat (endogen). Kaitannya dengan pengaruh langsung dapat dilihat pada tabel 5 dengan hasil uji koefisien determinan yaitu:

Tabel 4

Hasil Uji Koefisien Determinan Model Summary

\begin{tabular}{l|c|r|r|r}
\hline Model & R & R Square & $\begin{array}{c}\text { Adjusted R } \\
\text { Square }\end{array}$ & \multicolumn{2}{|c}{$\begin{array}{c}\text { Std. Error of the } \\
\text { Estimate }\end{array}$} \\
\hline 1 &, $695^{\mathrm{a}}$ &, 483 &, 475 &, 05008
\end{tabular}


Pengaruh Kinerja Lingkungan Terhadap Kinerja Keuangan Dengan Corporate Responsibility Sebagai Variabel Intervening Pada Perusahaan Manufaktur Yang Terdaftar Terdaftar Di Bursa Efek Indonesia Tahun 2015 - 2017

Berdasarkan tabel diatas, nilai koefisien determinasi sebesar 0,475. Hal ini menunjukkan bahwa kemampuan variabel independen yaitu kinerja lingkungan dapat menjelaskan Kinerja Keuangan hingga sebesar $47,5 \%$. Sedangkan sisanya $52.5 \%$ dijelaskan oleh faktor - faktor lain selain kinerja lingkungan. Serta nilai koefisien residu (e) sebesar 0.719.

Selanjutnya hasil uji $\mathrm{T}$ menunjukkan untuk variabel kinerja lingkungan diperoleh $\mathrm{t}_{\text {hitung }}$ sebesar 1,687 dengan nilai signifikansi sebesar 0,096. Nilai signifikan untuk variabel kinerja lingkungan menunjukkan nilai di atas tingkat signifikansi sebesar 0,05 yang menyimpulkan bahwa tidak adanya pengaruh kinerja lingkungan terhadap kinerja keuangan. Dan diperoleh nilai Standardized Coefficients Beta sebesar 0,162 merupakan nilai Path atau jalur p1. Sedangkan untuk nilai Unstandardized Coefficients Beta sebesar 0,498. Dari hasil tersebut menunjukkan bahwa kinerja lingkungan tidak berpengaruh terhadap kinerja keuangan.

Tabel 5

Hasil Uji T

\begin{tabular}{|c|c|c|c|c|c|c|}
\hline \multirow{2}{*}{\multicolumn{2}{|c|}{ Model }} & \multicolumn{2}{|c|}{$\begin{array}{c}\text { Unstandardized } \\
\text { Coefficients }\end{array}$} & \multirow{2}{*}{$\begin{array}{c}\begin{array}{c}\text { Standardized } \\
\text { Coefficients }\end{array} \\
\text { Beta } \\
\end{array}$} & \multirow[t]{2}{*}{$\mathrm{T}$} & \multirow[t]{2}{*}{ Sig. } \\
\hline & & $\mathrm{B}$ & Std. Error & & & \\
\hline \multirow{3}{*}{1} & (Constant) & $-4,088$ & ,850 & & $-4,809$ &, 000 \\
\hline & Kinerja Lingkungan & , 498 & ,295 &, 162 & 1,687 &, 096 \\
\hline & $\mathrm{Csr}$ & 13,236 & 2,150 & ,592 & 6,156 & , 000 \\
\hline
\end{tabular}

Selanjutnya apabila kaitannya dengan pengaruh tidak langsung, hasil uji koefisien determinan pada tabel 6 menunjukkan nilai koefisien determinasi (adjusted $\mathrm{R}$ square) sebesar 0.183. Hal ini menunjukkan bahwa kemampuan variabel independen yaitu kinerja lingkungan dan CSR dapat menjelaskan kinerja keuangan hanya sebesar 18,3\%. Serta nilai koefisien residu (e) sebesar 0.917.

Tabel 6

Hasil uji Koefisien Determinan

Model Summary

\begin{tabular}{l|r|r|r|r}
\hline Model & R & R Square & $\begin{array}{c}\text { Adjusted R } \\
\text { Square }\end{array}$ & $\begin{array}{c}\text { Std. Error of the } \\
\text { Estimate }\end{array}$ \\
\hline 1 &, $427^{\mathrm{a}}$ &, 183 &, 159 &, 42598 \\
\hline \multicolumn{2}{l}{ a. Predictors Constant : Kinerja Lingkungan }
\end{tabular}

Berdasarkan tabel 7 hasil pengujian parsial menunjukkan bahwa nilai $t_{\text {hitung }}$ pada variabel kinerja lingkungan sebesar 3,339 dengan signifikansi sebesar 0,001. Apabila ditabel lihat dari keterangan tersebut maka nilai signifikansi untuk variabel kinerja lingkungan menunjukkan nilai di bawah 0,05 , sehingga dapat disimpulkan bahwa kinerja lingkungan berpengaruh terhadap CSR Dan diperoleh nilai Standardized Coefficients Beta sebesar 0,371 merupakan nilai Path atau jalur p2. Sedangkan untuk nilai Unstandardized Coefficients Beta sebesar 0,051. Hal ini menunjukkan bahwa kinerja lingkungan berpengaruh dan signifikan terhadap cormporate social responsibility.

Tabel 7

Hasil Pengujian Parsial

Coefficients $^{\mathrm{a}}$

\begin{tabular}{|c|c|c|c|c|c|c|}
\hline \multirow{2}{*}{\multicolumn{2}{|c|}{ Model }} & \multicolumn{2}{|c|}{ Unstandardized Coefficients } & \multirow{2}{*}{$\begin{array}{c}\text { Standardized } \\
\text { Coefficients } \\
\text { Beta }\end{array}$} & \multirow[t]{2}{*}{$\mathrm{t}$} & \multirow[t]{2}{*}{ Sig. } \\
\hline & & B & Std. Error & & & \\
\hline \multirow[b]{2}{*}{1} & (Constant) & 146 & ,044 & & 3,319 &, 001 \\
\hline & $\begin{array}{l}\text { Kinerja } \\
\text { Lingkungan }\end{array}$ & ,051 &, 015 & ,371 & 3,339 & 001, \\
\hline
\end{tabular}


Pengaruh Kinerja Lingkungan Terhadap Kinerja Keuangan Dengan Corporate Responsibility Sebagai Variabel Intervening Pada Perusahaan Manufaktur Yang Terdaftar Terdaftar Di Bursa Efek Indonesia Tahun 2015 - 2017

Besarnya nilai e1 $=\sqrt{ }(1-0,159)=0,917$, hasil e1 merupakan akar dari $(1-(\mathrm{R}-$ Square $))$ pada persamaan 1 dilihat pada tabel model summary. Dan untuk nilai e2 $=\sqrt{ }(1-0,483)=0,719$, hasil tersebut diperoleh dari akar (1- (R-Square) pada persamaan 2.

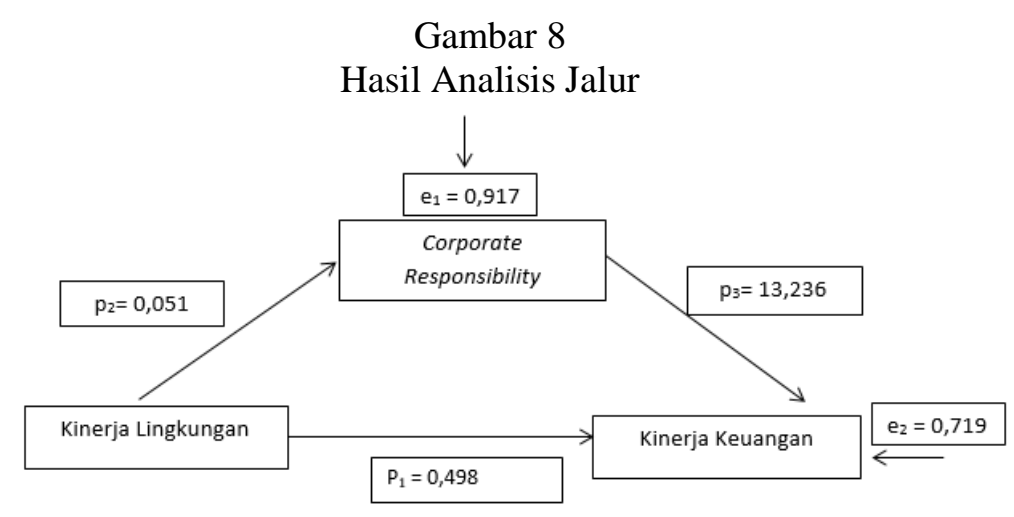

Berdasarkan pada gambar 8 hasil analisis jalur menunjukkan besarnya pengaruh Kinerja Lingkungan pada Corporate Social Responsibility adalah 0,051. Besarnya pengaruh langsung Kinerja Lingkungan pada Kinerja Keuangan adalah 0,498. Pengaruh Corporate Social Responsibility pada Kinerja Keuangan yaitu 13,236. Besarnya pengaruh Kinerja Lingkungan pada Kinerja Keuangan melalui Corporate Social Responsibility sebagai variabel intervening (pengaruh tidak langsung) harus dihitung dengan cara mengalikan koefisien tidak langsungnya yaitu $((0,051) \times 13,236)=0,675036$ sehingga pengaruh totalnya menjadi $(0,498+(0,051) \times 13,236))=1,173036$. Tingkat pengaruh tidak langsung Kinerja Lingkungan pada kinerja keuangan sebesar 1,173036 lebih besar dari koefisien hubungan langsung 0,498 berarti dapat disimpulkan bahwa hubungan yang sebenarnya adalah hubungan tidak langsung yaitu Kinerja Lingkungan mempengaruhi Kinerja Keuangan melalui Corporate Social Responsibility sebagai variabel intervening lebih besar daripada pengaruh langsung Kinerja Lingkungan dengan Kinerja Keuangan.

\subsection{Pembahasan}

Berdasarkan hasil uji yang telah dilakukan hipotesis pertama (H1) yaitu Kinerja Lingkungan tidak berpengaruh terhadap Kinerja Keuangan menunjukkan bahwa nilai koefisien jalur pengaruh Kinerja Lingkungan terhadap Kinerja Keuangan sebesar 0,498. Adapun nilai signifikansi sebesar $0,096>0,05$. Hal ini menunjukkan semakin tinggi kinerja lingkungan maka kinerja keuangan akan semakin menurun. Jadi dapat disimpulkan semakin tinggi kinerja lingkungan tersebut berarti semakin menurunkan kinerja keuangan dalam perusahaan. Dengan demikian kinerja lingkungan tidak memberikan kontribusi terhadap kinerja keuangan perusahaan. Hasil penelitian ini konsisten dengan penelitian yang dilakukan oleh Putri dan Herawati (2017), Nor et al (2016), Pertiwi et al (2015), Rosyid (2015), dan Rakhiemah (2009) menemukan bahwa tidak ada hubungan yang signifikan antara kinerja lingkungan terhadap kinerja keuangan. Kinerja lingkungan tidak berpengaruh terhadap kinerja keuangan diduga karena proporsi kepemilikan manajerial di perusahaan sampel relatif masih sangat kecil. Hal ini memperlihatkan bahwa rata-rata perusahaan memperoleh tingkat cukup baik (biru), artinya perusahaan telah melakukan upaya pengelolaan lingkungan yang dipersyaratkan sesuai dengan ketentuan dan atau peraturan perundang-undangan.

Selanjutnya pada hipotesis kedua (H2) yaitu kinerja lingkungan berpengaruh dan signifikan terhadap corporate social responsibility. Hal ini berdasarkan hasil analisis diperoleh nilai koefisien jalur pengaruh corporate social responsibility terhadap kinerja keuangan sebesar 0,051. Adapun nilai signifikansi sebesar 0,001 < 0,05. Hasil ini menunjukkan bahwa kinerja lingkungan memiliki pengaruh dan signifikan terhadap corporate social responsibility. Hasil penelitian ini juga didukung oleh penelitian yang dilakukan oleh Al-Tuwaijri (2004), Suratno dkk (2006) dan Magdalena (2016), menjelaskan bahwa implementasi dari corporate social responsibility dapat mempengaruhi kinerja lingkungan.

Dalam penelitian ini variable intervening merupakan variabel penyela/antara yang terletak di antara variabel independen dan variabel dependen sehingga variabel independen tidak langsung 
Pengaruh Kinerja Lingkungan Terhadap Kinerja Keuangan Dengan Corporate Responsibility Sebagai Variabel Intervening Pada Perusahaan Manufaktur Yang Terdaftar Terdaftar Di Bursa Efek Indonesia Tahun 2015 - 2017

memengaruhi berubahnya atau timbulnya variabel dependen. Dalam hipotesis tiga (H3) kinerja lingkungan berpengaruh terhadap kinerja keuangan dengan corporate social responsibility sebagai variable intervening pada Perusahaan Manufaktur yang terdaftar di Bursa Efek Indonesia (BEI). Besarnya pengaruh langsung yaitu 0,498 sedangkan besarnya pengaruh tidak langsung harus dihitung dengan mengalihkan koefisien tidak langsungnya yaitu yaitu $((0,051) \times 13,236)=0,675036$ sehingga pengaruh totalnya menjadi $(0,498+(0,051) \times 13,236))=1,173036$ dengan nilai t hitung 2,9466 lebih besar dari nilai t tabel yaitu 1,995 dengan signifikansi 0,05 , hal ini menunjukkan bahwa nilai koefisien mediasi 2,9466 berpengaruh signifikan memediasi Kinerja Lingkungan dan Kinerja Keuangan.

\section{Kesimpulan Dan Saran}

\subsection{Kesimpulan}

Berdasarkan permasalahan penelitian, kajian teori, hasil penelitian, dan pembahsan dapat disimpulkan bahwa Kinerja Lingkungan tidak memiliki berpengaruh terhadap kinerja keuangan, Kinerja Lingkungan memiliki pengaruh dan signifikan terhadap Corporate Social Responsibility dan Corporate Social Responsibility dapat mediasi hubungan Kinerja Lingkungan dan kinerja keuangan.

\subsection{Saran}

Berdasarkan kesimpulan dan keterbatasan didalam penelitian, dapat disampaikan beberapa saran bagi peneliti selanjutnya yaitu bisa menggunakan ukuran kinerja keuangan antara lain Return On Equity (ROE), Earning Per Share (EPS) dan Price Earning Ratio (PER); dapat menggunakan sektor perusahaan yang berbeda sebagai sampel maupun dengan menambah periode waktu penelitian untuk memperluas pengujian dan bagi investor, berdasarkan hasil penelitian diharapkan dapat memperhatikan variabel kinerja perusahaan yang diproksikan dengan Tobins $Q$ yang berpengaruh secara signifikan terhadap Corporate Social Responsibility sebelum mengambil keputusan dalam melakukan investasi dipasar modal.

\section{Daftar Pustaka}

Abdul Aziz Nurul Ikhsan, Harjum Muharam. 2016. Pengaruh Kinerja Lingkungan Terhadap Kinerjakeuangan: Studi

Pada Perusahaan Yang Terdaftar Di Kementerian Lingkungan Hidup Dan Listing Di Bei (Periode 2008-2014). Diponegoro Journal Of Management Volume 5, Nomor 3, Halaman 1-11 . ISSN (Online): 2337-3806

Almar, Multafia, Rima Rachmawati, Dan Asfia Murni. 2012. "Pengaruh Pengungkapan Corporate Social Responsibility (CSR) Terhadap Profitabilitas Perusahaan". Prosiding Seminar Nasional Akuntansi - Bisnis (SNAB) 2012, ISSN: 2252-3936, 27 Maret 2012.

Almilia, Luciana Spica. 2008. Faktor-Faktor yang Mempengaruhi Pengungkapan Sukarela Internet Financial and

Sustainbillity Reporting. JAAI. Vol. 12 No.2 hal. 117-131.

Al-Tuwaijri S.A. et al. 2004. The Relation Among Environmental Disclosure, Environmental Performance, dan Economic Performance : A Simultenaous Equation Approach. Accounting Environment Journal. USA. 5-10.

American Institute Of Certified Public Accountants. 1977. Statement On Auditing Standar 20. Required communication Of Material Weaknesses In Internal Accounting Control. New York: AICPA.

Angelia, D., \& Suryaningsih, R. (2015). The effect of Environmental Performance And Corporate Social Responsibility Disclosure Towards Financial Performance (Case Study to Mnufacture, Infrastructure, And Service Companies That Listed At Indonesia Stock Exchange. Procedia Social and Behavioral Sciences 211, 348-355.

Atmaja, L. S. (2008). Teori dan Praktik Manajemen Keuangan. Yogyakarta: Penerbit ANDI.

BAPEPAM, SE-38/PM/1996 tentang Pedoman Kewajiban Pengungkapan Perusahaan.

Boubaker, S Lakhal. et al. 2012. The Determinants of Web-Based Corporate Reporting in Franc. Managerial Auditing Journal, Vol. 27 No. 2, pp. 126-155.

Brigham, F. Eugene. et al. 2006. Fundamentals Of Financial Management. Jakarta: Salemba Empat. 
Pengaruh Kinerja Lingkungan Terhadap Kinerja Keuangan Dengan Corporate Responsibility Sebagai Variabel Intervening Pada Perusahaan Manufaktur Yang Terdaftar Terdaftar Di Bursa Efek Indonesia Tahun 2015 - 2017

Bergmann, A. 2016. The link between corporate environmental and corporate financial performance Viewpoints from practice and research. Sustainability, 8, 1219

Chang, K. (2015). The Impaccts of Environmental performance and Propensity Disclosure on Financial Performance: Empiricalo Evidence from Unbalanced Panel Data of Heavy-Polution Industries in China. Journal of Industrial Engineering and Management , 8(1): 21-36.

Deegan, Craig. 2002. The Legitimacing Effect Of Social and Environmental Disclouser- A Theoritical Foundation. Accounting, Auditing and Accountability. Journal, 15 (3) 282-311.

Dowling, J. And Prefer, J. 1975. Organizational legitimacy: Social Value and Organizational Behavior. Pacific Sociological Review, 18, 122-136.

Elkington, J., 1997. Cannibals with Forks. The Triple Bottom Line of 21 st century.

Ghozali, Imam. 2016. Aplikasi Analisis Multivariate dengan Program SPSS 23. Semarang: Badan Penerbit Universitas Diponegoro.

Gantino, Rilla. 2016 Pengaruh Corporate Social Responsibility Terhadap Kinerja Keuangan Perusahaan Manufaktur yang Terdaftar di Bursa Efek Indonesia periode 2008-2014. Jurnal Dinamika Akuntansi dan Bisnis Vol. 3(2), pp 19-32

Haninun, H., Lindrianasari, L. and Denziana, A. (2018) "The effect of environmental performance and disclosure on financial performance", Int. J. Trade and Global Markets, Vol. 11, No. 1/2, pp.138-148.

Harjosoemarto, Sumarnio. 1994. Analisis Rasio Untuk Menilai Kinerja Keuangan Perusahaan Publik. Informasi Pasar Modal. Yogyakarta.

Horváthová, E. 2012. The impact of environmental performance on firm performance: Short-term costs and long term benefits. Ecol. Econ. 84, 91-97.

I, Ghazali. A, Chariri. 2007. Teori Akuntansi. Semarang : Badan Penerbit Universitas Diponegoro.

Indrawan, D.C. 2011. Pengaruh orporate Social Responsibility Terhadap Kinerja Perusahaan. Skripsi pada Universitas Diponegoro Semarang.

Ja'far, S, Muhammad dan Arifah, Dista Amalia. 2006. Pengaruh Dorongan Manajemen Lingkungan, Manajemen Lingkungan Proaktif dan Kinerja Lingkungan Publik Environmental Reporting. Simposium Nasional Akuntansi IX.

Januarti, Indira dan Dini Aprianti. 2005. "Pengaruh Tanggung Jawab Sosial Perusahaan Terhadap Kinerja Keuangan”. Jurnal Maksi, Vol. 5, No.2, Hal 227 - 243 Semarang: Fakultas Ekonomi Universitas Diponegoro.

Jumingan. 2006. Analisis Laporan Keuangan. Cetakan Pertama, PT Bumi Aksara, Jakarta.

Kasmir. 2015. Analisis Laporan Keuangan. Jakarta: Rajawali pers.

Li, J. He, H. Liu, H. Su, C. 2017. Consumer Responses To Corporate Environmental Actions In China: An Environmental Legitimacy Perspective. J. Bus: Ethics, 143, 589-602

Lindawati , Ang Swat Lin . Puspita, Marsella Eka. 2015. Corporate Social Responsibility: Implikasi Stakeholder dan Legitimacy Gap Dalam Peningkatan Kinerja Perusahaan.

Lioui, A. Sharma, Z. Environmental corporate social responsibility and financial performance: Disentangling direct and indirect effects. Ecol. Econ. 78, 100-111.

Martani, Dwi. Dkk. 2012. Akuntansi Keuangan Menengah Berbasis PSAK. Jakarta: Salemba Empat

McWilliams, A. Siegel, D. 2000. Corporate social responsibility and financial performance: Correlation or misspecification? . Strateg. Manag. J. 21, 603-609.

Mirza, T. 1997. EVA sebagai Alat Penilaian. Usahawan: Jakarta

Mikolajec, Magdalena. 2016. The Relationship Between Corporate Social Responsibility And Corporate Financial Performance - Evidence From Empirical Studies. Comparative Economic Research, Volume 19, Number4

Muhammad, N. et al. 2015. The relationship between environmental performance and financial performance in periods of growth and contraction: Evidence from Australian publicly listed companies. J. Clean. Prod. 102, 324-332.

Paul, Catherine J Morrison. 2006. Corporate Social Responsibility and Economic Performance. Departmen Of Agricultural and Resource Economics University Of California.

Permana, Virgiwan Aditya. 2012. Pengaruh Kinerja Lingkungan dan Karekteristik Perusahaan Terhadap Corporate Social Responsibility. Diponegoro Journal Of Accounting Volume1, Nomor 2.

Vol : 7, no 2, 2019

Jurnal Akuntansi Keuangan dan Perpajakan Indonesia 
Pengaruh Kinerja Lingkungan Terhadap Kinerja Keuangan Dengan Corporate Responsibility Sebagai Variabel Intervening Pada Perusahaan Manufaktur Yang Terdaftar Terdaftar Di Bursa Efek Indonesia Tahun 2015 - 2017

Pertiwi, Intan., Nurleli dan Epi Fitriah. 2015. "Pengaruh Kinerja Lingkungan dan Pengungkapan Lingkungan terhadap Kinerja Keuangan (Studi Empiris pada Perusahaan Pertambangan yang Terdaftar di Bursa Efek Indonesia dan Mengikuti PROPER Periode 2010-2013)”. Jurnal Universitas Islam Bandung. Bandung.

Pratama, Yoga Andar. et al. 2017. The Influence Of Good Corporate Governance And Financial Leverage To Profitability With Corporate Social Responsibility As Intervening Variable (Case Strudy On Manufacturing Companies Listed On Bei Period 2012-2016).

Putri, Shelinda Arisandi dan Sinta Dewi Herawati. 2017. Pengaruh Kinerja Lingkungan Terhadap Kinerja Keuangan. Seminar nasional Akuntansi dan Bisnis (SNAB) Universitas Widyatama.

Rosyid, A. (2015). Pengaruh Kinerja Sosial dan Kinerja Lingkungan Terhadap Kinerja Keuangan. Vol.12 No. $1,72-85$.

Rakhiemah, Aldilla Noor. 2009. Pengaruh Kinerja Lingkungan Terhadap Corporate Social Responsibility dan Kinerja Finansial. Universitas Airlangga.

Restuningdiah, Nurika.2010. Kinerja Lingkungan Terhadap Return On Asset Melalui Corporate Responsibility Disclouser. Jurnal Keuangan dan Perbankan, Vol 14, No 2. 191-204

Riley E, Dunlap. Rik, Scarce .1991. Environmental problem and protection” Volume 55, Issue 4, 1 Pages 651-672,

https://doi.org/10.1086/269288

Soemarso, R. 2005. Akuntansi Suatu Pengantar. Jakarta: PT Rineka Cita

Sucipto. 2003. Penilaian Kinerja Keuangan. Medan. USU Digital Library.

Sugiyono. 2013. Metode Penelitian Kuantitatif Kualitatif Dan R\&D. Bandung: Alfabeta.

Suratno, Ignatius Bondan, Darsono Dan Siti Mutmainah.2006. Pengaruh Environmental Disclouser dan Economic Performance terhadap Environmental Disclouser dan Economic Performance (Studi Empiris Pada Perusahaan Manufaktur yang Terdaftar Di Bursa Efek Jakarta Periode 20012004). Simposium Nasional Akuntansi 9, (23-26 Agustus) 2006, Padang

Sutrisno. 2009. Manajemen Keuangan Teori, Konsep dan Aplikasi. Ekonisia, Yogyakarta. The statement of finacial accounting concept (SFAC) No 1. 1978. Financial Accounting Standar Board (FASB)

Verrecchia, R.E. (1983) Discretionary Disclosure. Journal of Accounting and Economics, 5, 179-194. http://dx.doi.org/10.1016/0165-4101(83)90011-3

https://www.globalreporting.org/standards/gri-standards-download-center/

http://iaiglobal.or.id

http://idx.co.id

http://www.menlhk.go.id 